\title{
An X-prolyl dipeptidyl aminopeptidase (pepX) gene from Lactobacillus helveticus
}

\author{
Erkki Vesanto, ${ }^{1}$ Kirsi Savijoki, ${ }^{1}$ Terhi Rantanen, ${ }^{1}$ James L. Steele ${ }^{2}$ \\ and Airi Palva ${ }^{1}$
}

1 Agricultural Research Centre of Finland, Food Research Institute, Jokioinen 31600, Finland

2 Department of Food Science, University of Wisconsin-Madison, Wisconsin 53706, USA
Author for correspondence: Airi Palva. Tel: +358 16 4188277. Fax: +358 164384550. e-mail: airi.palva@mtt.fi

The X-prolyl dipeptidyl aminopeptidase gene (pepX) of an industrially used Lactobacillus helveticus strain has been detected by nucleic acid hybridization, cloned, characterized and sequenced. One ORF of 2379 bp with coding capacity for a $90.6 \mathrm{kDa}$ protein (PepX) was found. The ORF was preceded by a typical prokaryotic promoter region. An inverted repeat structure with $\Delta G$ of $-84.1 \mathrm{~kJ} \mathrm{~mol}^{-1}$ was found downstream of the coding region. The deduced amino acid sequence of the 90.6 kDa protein showed 49.3, 49.4 and $77.7 \%$ homology with the PepX proteins from Lactococcus lactis subsp. lactis, LC. lactis subsp. cremoris and Lactobacillus delbrueckii subsp. lactis, respectively. Northern blotting revealed a 2.6 kb transcript and one transcription start site was identified via primer extension analysis using an A.L.F. sequencer. In a bioreactor study, the expression of pepX in $\mathbf{L b}$. helveticus was studied as a function of growth. Transcription of pepX was typical of exponential growth phase expression. The pepX gene has been cloned into pKK223-3 and expressed at a high level in Escherichia coli JM105. PepX was purified to homogeneity by ion-exchange and hydrophobic interaction chromatography. Optimum PepX activity was observed at pH 6.5 and $45^{\circ} \mathrm{C}$. According to gel filtration analysis, PepX is a dimer of $165 \mathrm{kDa}$. The enzyme was inactivated by heavy metal ions such as $\mathrm{Cu}^{2+}, \mathrm{Cd}^{2+}$ and $\mathrm{Zn}^{2+}$. EDTA and 1,10-phenanthroline did not decrease PepX activity significantly. It was completely inhibited by p-hydroxymercuribenzoate and reactivated by adding $D T$, and strongly inhibited by PMSF. PepX is thus a metal-independent serine peptidase having functional sulfhydryl groups at or near the active site.

Keywords: Lactobacillus belveticus, X-prolyl dipeptidyl aminopeptidase, peptidases

\section{INTRODUCTION}

Lactic acid bacteria play an important role in a variety of food fermentations. Strains of lactococci and lactobacilli used in dairy fermentations are fastidious organisms which require a variety of amino acids for growth. Since the concentrations of small peptides and amino acids in milk are insufficient to support their growth to high density, these bacteria are dependent on a complex proteolytic system for the liberation of amino acids from milk proteins. The proteolytic system is composed of a cell-envelope-associated proteinase, membrane-bound

Abbreviations: gly-pro-pNA, L-glycyl-L-prolyl-p-nitroanilide; PepX, Xprolyl dipeptidyl aminopeptidase; $p H M B$, $p$-hydroxymercuribenzoate.

The EMBL, GenBank and DDBJ accession number for the nucleotide sequence reported in this paper is $Z 48236$. transport systems, and numerous cytoplasmic peptidases. Recently, extensive biochemical and genetic analyses of individual components of the proteolytic system of lactic acid bacteria and their role in cheese ripening and flavour formation has been conducted (Kok, 1990; Pritchard \& Coolbear, 1993; Tan et al., 1993; Visser, 1993; Kok \& De Vos, 1994). The major milk proteins, caseins, are rich in the imino acid proline (Fox, 1989) and specialized enzymes are required to hydrolyse peptide bonds involving proline residues; therefore, proline-specific peptidases such as Xprolyl dipeptidyl aminopeptidase (PepX), aminopeptidase $\mathrm{P}$, proline endopeptidase, proline iminopeptidase, prolinase and prolidase are thought to be important components of these proteolytic systems (Kok \& De Vos, 1994; Baankreis \& Exterkate, 1991). PepX cleaves dipeptidyl residues from peptides by hydrolysing the peptide bond at the carboxyl side of the proline residue 
when this imino acid is the penultimate $\mathrm{N}$-terminal residue. In addition to peptidase activity, PepX also has amidase and esterase activities (Yoshpe-Besancon et al., 1994).

Casey \& Meyer (1985) first reported the presence of PepX in lactic acid bacteria. PepX has now been purified from a wide range of lactic acid bacteria including Streptococcus thermophilus (Meyer \& Jordi, 1987), Lactococcus lactis subsp. cremoris (Kiefer-Partsch et al., 1989; Booth et al., 1990), Lc. lactis subsp. lactis (Zevaco et al., 1990), Lactobacillus delbrueckii subsp. bulgaricus (Atlan et al., 1990; Miyakawa et al., 1991; Bockelmann et al., 1991), Lb. delbrueckii subsp. lactis (Meyer \& Jordi, 1987), Lb. acidophilus (Bockelmann et al., 1991), Lb. casei subsp. casei (Habibi-Najafi \& Lee, 1994) and Lb. belveticus (Khalid \& Marth, 1990; Miyakawa et al., 1994). However, $p e p X$ genes have only been cloned and sequenced from Lc.lactis subsp. cremoris (Mayo et al., 1991), Lc. lactis subsp. lactis (Nardi et al., 1991) and Lb. delbrueckii subsp. lactis (MeyerBarton et al., 1993).

In this paper we describe the cloning, DNA sequencing, mRNA analysis and expression of the pepX gene of $L b$. belveticus 53/7. Also overexpression, purification and characterization of the cloned $L b$. belveticus PepX from Eschericbia coli is described.

\section{METHODS}

Bacterial strains, plasmids and growth conditions. $L b$. belveticus strain $53 / 7$ is an industrial starter from the collection of Valio Ltd (Helsinki, Finland). Lb. belveticus was cultivated in MRS broth (Difco) at $42^{\circ} \mathrm{C}$ without shaking. Bioreactor cultivation was as described previously (Vesanto et al., 1994). Escherichia coli strains $\mathrm{DH} 5 \alpha \mathrm{F}^{\prime}$ (Woodcock et al., 1989) and JM105 (Pharmacia) were grown in Luria broth. Erythromycin (500 $\left.\mu \mathrm{g} \mathrm{ml}^{-1}\right)$ or ampicillin $\left(25-50 \mu \mathrm{g} \mathrm{ml}^{-1}\right)$ was added to the growth medium when the pJDC9 and pKK223-3 (Pharmacia) vectors, respectively, were used in E. coli.

Construction and screening of a $\mathbf{L b}$. helveticus genomic library. A $L b$. belveticus genomic library was constructed in $\lambda$ gt10 using $\lambda$-DNA in vitro packaging and $\mathrm{cDNA}$ rapid cloning modules (igt10; Amersham). Instead of the Amersham cDNA rapid adaptor ligation module, a RiboClone EcoRI Linker System (Promega) was employed.

Oligonucleotide synthesis. Oligonucleotides were synthesized with an Applied Biosystems DNA/RNA synthesizer model 392 and purified by ethanol precipitation or with NAP-10 columns (Pharmacia).

Amplification of DNA by PCR. DNA was amplified by PCR in reaction conditions recommended by the manufacturer of Dynazyme DNA polymerase (Finnzymes). The specific primer pair used was 5' CAACGGATCCGCATGCTCAAGCAGCTTAAG $3^{\prime}$ and 5' CTGAGGATCCAGTCGACAAAGGCGGC $3^{\prime}$, giving rise to a $2.8 \mathrm{~kb}$ DNA fragment carrying the $p e p X$ gene. For construction of an overexpression system for PepX in $E$. coli two synthetic primers were designed: $5^{\prime}$ GGTACCCGGGCTGACAAAGGAGAAAAATATG $3^{\prime}$ and $5^{\prime}$ TGATCCCGGGGATCAAACGGGTTATGGC 3', giving rise to a $2.5 \mathrm{~kb}$ DNA fragment carrying the $p e p X$ gene.

DNA sequencing. Sequencing was performed on an A.L.F. DNA Sequencer (Pharmacia). The dideoxy-sequencing reactions (Sanger et al., 1977) were performed according to the AutoRead Sequencing Kit manual (Pharmacia). Both DNA strands were sequenced using $\lambda \mathrm{gt} 10$ - and pUC19-specific primers and different sequence-specific oligonucleotides for primer walking.

Other DNA methods. Plasmid DNAs from E. coli clones were isolated by using Wizard Minipreps (Promega) or FlexiPrep (Pharmacia) kits. Restriction enzymes were used as recommended by the manufacturers. Ligations and other standard DNA methods were according to Sambrook et al. (1989). E. coli strains were transformed by electroporation using a Bio-Rad Gene Pulser.

RNA isolation, Northern (RNA) blotting and primer extension. Total RNA was isolated from $L b$. belveticus cells as described by Vesanto et al. (1994). RNA gel electrophoresis and Northern blotting were performed as described by Hames \& Higgins (1985). Total Lb. belveticus 53/7 RNA, denatured with glyoxal and dimethyl sulfoxide, was run on a $1.0 \%(\mathrm{w} / \mathrm{v})$ agarose gel with $10 \mathrm{mM}$ sodium phosphate buffer, $\mathrm{pH} \mathrm{6.5,} \mathrm{followed} \mathrm{by}$ transfer to a positively charged nylon membrane (Boehringer Mannheim). Hybridization probes were labelled with digoxigenin-dUTP (DIG, Boehringer-Mannheim). A DIG luminescent detection kit (Boehringer) was used for hybrid detection. Primer extension was performed with total RNA isolated from exponentially growing cells essentially as described by Myöhänen \& Wahlfors (1993) using an A.L.F. DNA Sequencer (Pharmacia) with the fluorescein-labelled oligonucleotide 5' CTGCTGAAGTCCCAGACTTG 3'. Briefly, $40 \mu \mathrm{g}$ of DNA-free total RNA was ethanol-precipitated with the labelled primer $(10 \mathrm{pmol})$. For the reaction, $46 \mathrm{U}$ of avian myeloblastosis virus (AMV) reverse transcriptase was used. The reaction mixture was extracted with phenol/chloroform $1: 1$, $\mathrm{v} / \mathrm{v}$ ) and chloroform, ethanol-precipitated and dissolved in $4 \mu \mathrm{l}$ water. Stop buffer $(4 \mu \mathrm{l})$ from the AutoRead Sequencing Kit (Pharmacia) was added, and the whole mixture was loaded with sequencing reactions into a $6 \%(\mathrm{w} / \mathrm{v})$ sequencing gel. The sequencing reaction of pKTH2097, performed with the same primer, was used as the marker for the $5^{\prime}$ end determination. The transcription start site was determined by comparing the retention time of the primer extension product with that of the products from the sequencing reaction.

Peptidase activity assays. Bacterial colonies and $\lambda$ plaques were screened by a plate-staining procedure described by Nardi $e t$ al. (1991) using L-glycyl-L-prolyl- $\beta$-naphthylamide (Sigma) as the substrate in $50 \mathrm{mM}$ HEPES ( $\mathrm{pH} 7 \cdot 0$ ) buffer with Fast Garnet GBS sulfate salt (Sigma) $\left(2 \mathrm{mg} \mathrm{m}^{-1}\right)$. From liquid cultures, the enzyme activity was determined according to El Soda \& Desmazeaud (1982) using $2 \mathrm{mM}$ L-glycyl-L-prolyl- $p$-nitroanilide (gly-pro-pNA; Sigma) in $50 \mathrm{mM}$ HEPES (pH 7.0) buffer. $L b$. belveticus cells were disrupted with an Ultrasonic 2000 sonicator (Braun) or permeabilized by chloroform. During protein purification PepX activity was determined at $37^{\circ} \mathrm{C}$ using $1.2 \mathrm{mM}$ gly-pro- $p \mathrm{NA}$ in $50 \mathrm{mM}$ Tris $/ \mathrm{HCl}, \mathrm{pH} 7 \cdot 5$. The total volume of the reaction was $430 \mu \mathrm{l}$ and the reaction was stopped by the addition of $1 \mathrm{ml} \mathrm{30 \% (v/v)} \mathrm{acetic} \mathrm{acid.} \mathrm{The} \mathrm{release} \mathrm{of} p$ nitroaniline was followed at $410 \mathrm{~nm}$. Hydrolysis of $p \mathrm{NA}$ was linear in the range $0-1 \cdot 2$ absorbance units, where one unit corresponds to the release of $1 \mu \mathrm{mol} p$-nitroaniline $\mathrm{min}^{-1}$. A molar extinction coefficient of $8800 \mathrm{M}^{-1} \mathrm{~cm}^{-1}$ (Bockelmann et al., 1991) was used to calculate the specific enzyme activity as units (mg protein $)^{-1}$. The protein content was determined by the Bio-Rad protein assay using BSA (Sigma) as a standard. Diluted enzyme samples of $1 \mathrm{ml}$ were mixed with $250 \mu \mathrm{l}$ Coomassie reagent, and the absorbance was measured at $595 \mathrm{~nm}$. 
Computer analysis. The DNA sequences obtained from A.L.F. were assembled and analysed with the PC/GENE set of programs (Release 6.8, IntelliGenetics). The databases of EMBL and Swiss-Prot were used for searching for homologous protein and nucleic acid sequences.

Construction of an overexpression system for the $\boldsymbol{L} \boldsymbol{b}$. helveticus PepX in E. coli. The pepX gene was isolated by PCR. For this purpose two PCR primers were designed containing $X m a I$ sites at their $5^{\prime}$ ends for the cloning (see above). The XmaI fragment, carrying the structural gene of $p e p X$ with its own ribosome binding site, was ligated with the pKK223-3 vector (Pharmacia), downstream of the inducible tac promoter and transferred into the E. coli JM105 host (Pharmacia). The expression of PepX was characterized by cultivating the cells to a density of 50 Klett units (filter 66), followed by $1 \mathrm{mM}$ IPTG induction and measurement of product accumulation during $5 \mathrm{~h}$ by SDS-PAGE and measurement of PepX activity against the gly-pro- $p$ NA substrate.

Purification of PepX. The crude extract of E. coli JM105 carrying the $p e p X$ construct in $\mathrm{pKK} 223-3$ was prepared as follows. Luria broth $(1.8 \mathrm{l})$ supplemented with ampicillin $\left(50 \mu \mathrm{g} \mathrm{ml}^{-1}\right)$, was subcultured with $36 \mathrm{ml}$ of an overnight culture. Bacteria were grown to the cell density of 50 Klett units (filter 66), followed by induction of $p e p X$ expression with $1 \mathrm{mM}$ IPTG. Two hours after induction the cells were harvested by centrifugation $(8000 \mathrm{~g}, 20 \mathrm{~min})$ and washed with $200 \mathrm{mM}$ Tris $/ \mathrm{HCl}, \mathrm{pH} \mathrm{8.0.} \mathrm{The} \mathrm{pellet} \mathrm{was} \mathrm{resuspended} \mathrm{in} 54 \mathrm{ml}$ lysis buffer $(20 \mathrm{mM}$ Tris $/ \mathrm{HCl}, \mathrm{pH} 8.0,1 \mathrm{mM}$ EDTA, $0.5 \mathrm{mg}$ lysozyme $\mathrm{ml}^{-1}$ ) and gently stirred for $45 \mathrm{~min}$ at $4{ }^{\circ} \mathrm{C}$. The volume of the crude extract was brought up to $100 \mathrm{ml}$ and then treated with bovine pancreatic RNase (Sigma) and DNase I (Boehringer) for $30 \mathrm{~min}$ at room temperature. The cell debris was removed by centrifugation $\left(4^{\circ} \mathrm{C}, 10000 \mathrm{~g}, 40 \mathrm{~min}\right)$. The cell-free extract was fractionated by 50 and $80 \%(\mathrm{w} / \mathrm{v})$ $\left(\mathrm{NH}_{4}\right)_{2} \mathrm{SO}_{4}$ precipitations in two steps. The precipitates were collected by centrifugation $\left(4^{\circ} \mathrm{C}, 6000 \mathrm{~g}, 30 \mathrm{~min}\right)$, solubilized in $50 \mathrm{mM}$ Tris/ $\mathrm{HCl}, \mathrm{pH} 7.5(20 \mathrm{ml})$, and dialysed first against deionized water for $60 \mathrm{~min}$ and then overnight against $50 \mathrm{mM}$ Tris/ $\mathrm{HCl}, \mathrm{pH} 7 \cdot 5$.

Prior to Q-Sepharose chromatography the dialysed sample $(24 \mathrm{ml}$ ) was filtered through a $0.45 \mu \mathrm{m}$ membrane filter (Millex HA, Millipore). A Q-Sepharose column (gel bed $100 \mathrm{ml}$, diam. $5 \mathrm{~cm}$, Pharmacia) was equilibrated with the starting buffer (50 mM Tris/HCl, pH 7.5). After loading the sample, the column was washed until the absorbance at $280 \mathrm{~nm}$ was near zero. Proteins were eluted in a linear gradient of $0-0.3 \mathrm{M} \mathrm{NaCl}$ in starting buffer (flow rate $5 \mathrm{ml} \mathrm{min}^{-1}$, gradient volume $1 \mathrm{l}$, fraction size $10 \mathrm{ml}$ ), and the fractions were tested for gly-pro$p$ NA-hydrolysing activity. The active PepX fractions $(110 \mathrm{ml})$ were concentrated 110 -fold by ultrafiltration through a $30 \mathrm{kDa}$ cut-off membrane (Amicon). For the last purification step, $\mathrm{NaCl}$ was added to a final concentration of $4 \mathrm{M}$ to the concentrated fraction. Half of the concentrated fraction was centrifuged $\left(4^{\circ} \mathrm{C}, 10000 \mathrm{~g}, 10 \mathrm{~min}\right)$ and purified by hydrophobic interaction chromatography (Phenyl-Superose HR 5/5, Pharmacia). Proteins were eluted in a linear gradient of $4-0 \mathrm{M} \mathrm{NaCl}$ in $50 \mathrm{mM}$ Tris/ $\mathrm{HCl}$ buffer, $\mathrm{pH} 7.5$ (flow rate $0.5 \mathrm{ml} \mathrm{min}^{-1}$, gradient volume $15 \mathrm{ml}$, fraction size $1 \mathrm{ml}$ ), and assayed for gly-propNA-hydrolysing activity.

Determination of $\mathrm{pH}$ and temperature optima. For determination of the $\mathrm{pH}$ optimum in the range of $\mathrm{pH} 4-10$, a buffer system containing either MES, HEPES, malic acid or boric acid (50 mM each) was employed. Reactions were incubated at $37^{\circ} \mathrm{C}$

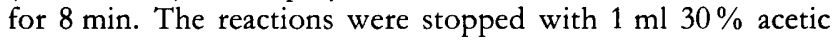

acid and the absorbance was measured at $410 \mathrm{~nm}$. The optimum temperature was estimated by the same method in the temperature range $0-70^{\circ} \mathrm{C}$ with $50 \mathrm{mM}$ MES, pH 6.5.

Inhibition studies. Potential inhibitors were added to final concentrations of $0 \cdot 1$ and $1 \mathrm{mM}$. Reaction mixtures were preincubated at room temperature for $30 \mathrm{~min}$ and contained $50 \mathrm{mM}$ MES buffer, pH $6.5(1.2 \mathrm{mM}$ gly-pro- $p$ NA was used as a substrate). Reactivation was performed by adding reactivating agent (final concentration $1 \mathrm{mM}$ ) to the reaction mixture and incubating for an additional $10 \mathrm{~min}$ at room temperature. Reactions were incubated at $40^{\circ} \mathrm{C}$ for $8 \mathrm{~min}$ and stopped with $30 \%$ acetic acid. The activities were compared with the untreated control, which was taken as $100 \%$.

Molecular mass determination. The molecular mass of the native PepX was determined by gel filtration chromatography (Superdex 75 and 200 HR 10/30, Pharmacia) equilibrated with

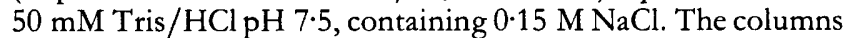
were calibrated with catalase $(232 \mathrm{kDa})$, aldolase $(158 \mathrm{kDa})$, albumin $(68 \mathrm{kDa})$, ovalbumin $(43 \mathrm{kDa})$ and chymotrypsinogen $(25 \mathrm{kDa})$. SDS-PAGE was performed with a $10 \%(\mathrm{w} / \mathrm{v})$ polyacrylamide gel (Laemmli, 1970). The gel was stained with Coomassie Brilliant Blue R250. MWH-SDS proteins (Pharmacia) were used as marker standards.

\section{RESULTS AND DISCUSSION}

\section{Cloning and sequence analysis of the pep $X$ gene from $L b$. helveticus $53 / 7$}

Southern hybridization was used to examine homology between a $1.5 \mathrm{~kb} E c o \mathrm{RI}-K \not n \mathrm{I}$ fragment probe derived from the Lb. belveticus CNRZ32 PepX gene (Nowakowski et al., 1993) and chromosomal DNA of Lb. helveticus 53/7. The Southern analysis gave positive results but the pepX gene could not be isolated from a Lb. belveticus gene library established in the $\mathrm{p} T Z 18 \mathrm{R}$ vector carrying large chromosomal inserts (approx. $7 \mathrm{~kb}$ ) (Varmanen et al., 1994), suggesting that the flanking regions of $p e p X$ may be harmful in $E$. coli. Instead, the $p e p X$ gene was finally isolated from a $L b$. belveticus $53 / 7$ genomic library established in $\lambda \mathrm{gt} 10$. Screening of 26000 plaques resulted in the detection of one positive clone. This clone was determined to contain an insert of $3 \cdot 6 \mathrm{~kb}$.

The DNA sequence analysis of the $3.6 \mathrm{~kb}$ insert revealed one ORF of $2379 \mathrm{bp}$ with the capacity to encode a protein of 793 amino acids with a calculated molecular mass of $90571 \mathrm{Da}$ (Fig. 1). Using primers designed up- and downstream of the ORF, the putative $p e p X$ gene was amplified by PCR, cloned into pJDC9 and designated pKTH2097. The E. coli clones carrying pKTH2097 were confirmed to encode PepX activity by demonstrating activity of permeabilized cells and in the in situ enzymic plate assay on PepX-specific substrates. The $p e p X$ starts with ATG at position 235 and a termination codon TAA is located at position 2614 (Fig. 1). A typical prokaryotic ribosome binding site, AGGAGA (Shine \& Dalgarno, 1974; Stormo et al., 1982) was identified 11 nucleotides upstream of the initiation codon. A putative promoter with -35 (TTGGTT) and -10 (TAAAAT) regions found 61 and 38 nucleotides upstream of the initiation codon, respectively, was identified. A putative $\rho$-independent type transcriptional terminator was found 13 nucleotides 
GCATGCTCAAGCAGCTTAAGCGTTCAATTTATTATTGCAATTTACGTCTPTTGTITTTTACTAAATAAATCAAAAAGTCCCATAAAAATATCCTTAATAAATAAAATCTAATTACTTATA - 120 TTATGGACTATTTTTATCTTACTTAAAATATTTCTTTATTGATTTCATTITTATTGTTCTCTCTCTTTAAACGGTAAAATATAAGGTAATAATACTGACAAAGAGAAAATATGAAA - 240 TATAACCAATATGCTTACGTTGAAACCGACTTTCAACAACAAGTTAAAGAATTAATCGATATCAACTTCTTACCTAAAAATTATCAAGTCTGGGACTTCAGCAGTCTTTTAGCTAAATTA - 360

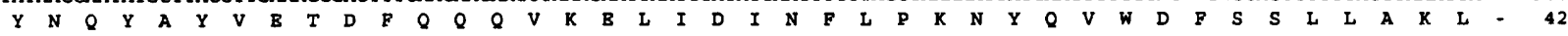
GTTAAAAATGCAATCGCTGAGGCTAAAACAGATGCCGCTAAAAATGCCAAACTTGCGGAATTTGCAGTTTCTGATCACCAGACCTTGGCTGATTTTCTTAAGGAAAGCCAACAGAAATT - 480

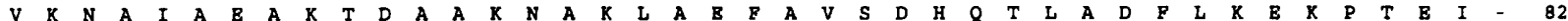
GGTACCGACAATTCTACAACGTAGCTCTGCAACTTCTTGGCTACCACGTCCACTACGACTATGATTTTGCTGATCCAACCGGTTTCATGCAAAGAAATGCTTTGCCATTTGTGCAAGAC - 600

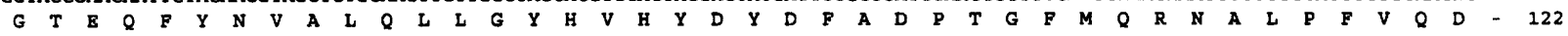
ATCAGCGACAATCAAAAATTAATCTCTGCCTTTTACCGCTTGCTCAATACCCGTGCTAAAAACGGACAAATCTTGCTCGATGTGATGGCAGGCAAAGGCTACTTTACTCAATTCTGGGGT - 720

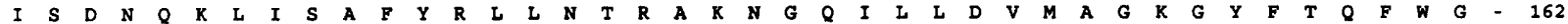

CAAAACAAGTTCAAGTTCTTCAATGGTAAATCTATCCCTGTTTTTGACACAAATAAGGTCATTCGTGAAGTCGTTTATGTCGAAACTGATCTTGATACTGACCATGATGGCAAGAGTGAT - 840

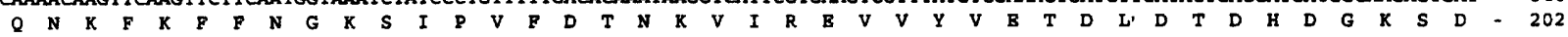

TTAATTCAAGTTACTGTTTCCGTCCTGAAGAAACTAATAAGGGCTTAAAGTACCTGCACTCTACACTGCATCCCCATACTTTGGCGGAATCATCGCCAACGAAAAACGCAACCATAAC - 960

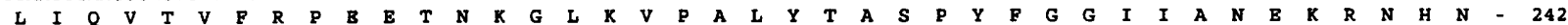
GTTGACGAAAATCTCTCTGACTCTACCGAATGGAATGATCCACAATACATTCACTCTCCAATCGTTAAGGCTGAAAAGCCAGATGGTTCAAGCCGTCCAGCTACAGAGGAGGCAGTGCAC - 1080

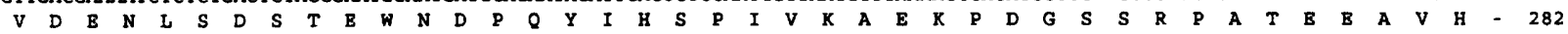
AAGTCCTCTTACCCATTAAACGATACATGCTAGCTCGCGGTTTTGCTAGCGTCTTTGCTGGTGCAATTGGTACTCGCGGCAGCGATGGTGTCCGCATCACTGGTGCTCCAGAAGAAACT - 1200

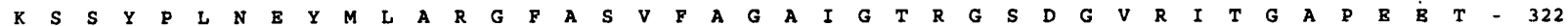
GAATCAGCTGCTGCAGTTATCGAATGGCTGCATGGTGATCGTGTTGCCTACACTGACAGAACCAGAACCGTTCAAACTACAGCTGATTGGTGCAACGGCAACATCGGTATGACCGGTCGT - 1320

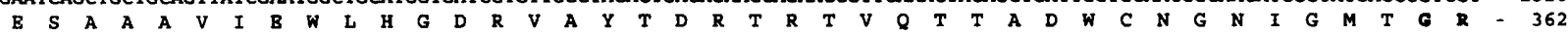
TCATATCTTGGTACTTTGCAAATCGCCATTGCCACAACTGGCGTTAAGGGTCTTAAGACTGTCGTTGCTGAAGCCGCAATTTCATCATGGTACGACTACTACCGTGAACATGGTTTGGTT - 1440

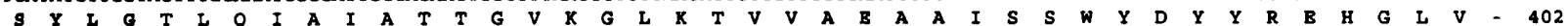
$+$ ATTGCTCCTGAAGCTTGCCAAGGTGAAGACCTTGATTTGCTCGCTGAAACCTGTCAATCAAACTTATGGGATGCCGGTTCATACCTTAAGATCAAGCCTGAATACGACAAAATGCAAAAG - 1560

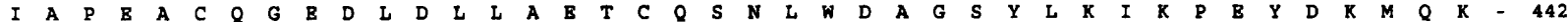
CAGTTGCGTGAAAAAGAAGACCGTAATACTGGTCAATACTCTGACTTCTGGGAAGCTAGAAACTACCGTCACCACGCTGATGGTATCAAATGCTCCTGGATTTCCGTTCATGGTTTAAAT - 1680

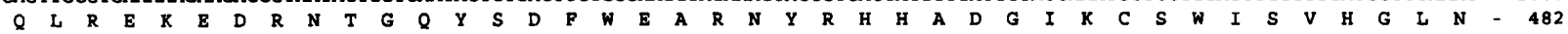
GACTGGAATGTTAAGCCAAAGAACGTTTACAAAATCTGGCAACTAGTTAAAAAGATGCCAATGAAGCATCACCTCTTCTTGCACCAAGGTCCGCACTACAATATGAACAACTTCGTTTCC - 1800

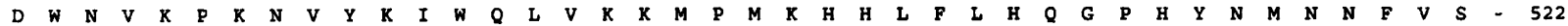
ATCGACTTTACAGACTTCATGAACCTCTGGTTTGTTCATGAACTTITAGGCATTGAAAATAATGCTTACAATCAATGGCCAACGGTTATGATTCAAGATAACTTCCAAGCTGACAAGTGG - 1920

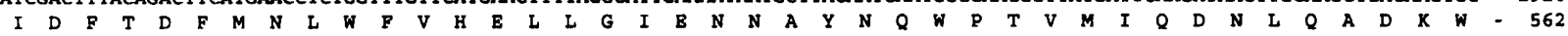
CATGAAGAACCTGACTGGAGCAATGATTTAGGCCAAGAAAAGATCTACTACCCTACTGATGAAGGCGAACTTITCCAAGATGGCAACGGCAAAGCACAAAAGTCCTTTACCGATGTTGGC - 2040

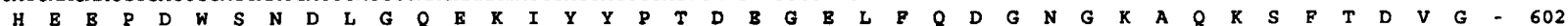
GGTATTGAATTCAAGAAAGCTGGTATTTCAGAAAGCGATTGGCAATACAAGTTCATTTGCGGTGATGAAAAATGGGCTAAGCCAAGTTTACGTTTTGAAACTGATGAATTTATCCACCCT - 2160

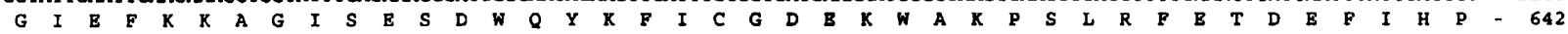
ACTACCATCGTGGGTCGTCCAGAAGTTAAAGTTAGAGTTTCTGCTAGTCTGCCAAAGGGTGAGATTTCCGTTGCCTTAGTTGAACTGGGCGAAAGACAACGACTTACCGCTACTCCTAAA - 2280

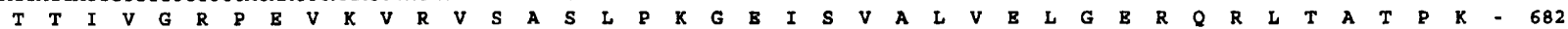
TTCTTAATGCGTGGCGGACAAGAATTAGGCTACCGTTTTGGCACTGACACTTTACAAGAATTTGTTCCAGATAANAAGACTAAAGCCAAGTTGATTACTAAGGCTCACATGAACTTGCAA - 2400

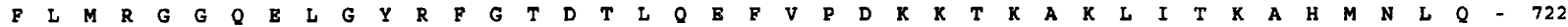
AACTTCAAGGATATGAAGAAGCCTGAAGCAATCGACGCCGATAAGTTCTACGACTTGGACTTCTTGCTTCAACCTACTTATTACACCATCCCATCTGGCAGCAAGCTTGCTTTGATCATT - 2520

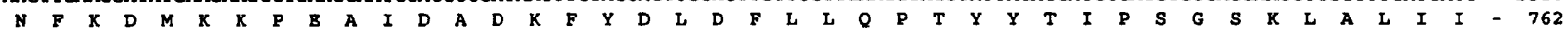
TATTCAACTGACCAAGGCATGACTAAGCGTCCGCTTGAAGATGAAACTTACACAATTGATTTAGCTAATACTGAAATCAAGTTTTATGAAAAATMATTAATCCTAACGAAAAGACAGGCA - 2640

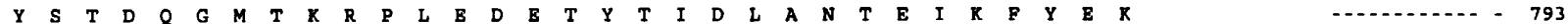

TTCAAATCGAATGCCTGTCTTTTTTTGCTATTCAAATAACTTTTTATACTCGCCATAACCCGTTTGATCAAGCTTATCATATGGAATAAATTTCAAAGCAGCCGAATTAATGCAATAACG - 2760 Th

Fig. 1. The nucleotide and deduced amino acid sequences of the $L b$. helveticus $53 / 7$ pep $X$ gene. The predicted -35 and -10 regions of the putative promoter are underlined. The transcription start site, determined by primer extension, is indicated by a vertical arrow. RBS refers to the putative ribosome binding site which is indicated by a dashed line. Conserved amino acid residues involved in the active site are indicated by bold type and the active site serine with an asterisk. The stop codon is written in bold type. The putative transcription terminator is shown with dashed arrows.

downstream from the stop codon with a $\Delta G$ of $-84.1 \mathrm{~kJ} \mathrm{~mol}^{-1}$ (Fig. 1).

The alignment (PALIGN program of PC/GENE) of the deduced amino acid sequence of $p e p X$ (793 amino acid residues) with those of the $p e p X$ genes from $L c$. lactis subsp. lactis (Mayo et al., 1991), Lc. lactis subsp. cremoris (Nardi et al., 1991; 763 amino acids) and Lb. delbrueckii subsp. lactis (Meyer-Barton et al., 1993; 792 amino acids) revealed overall homologies of $49 \cdot 3,49 \cdot 4$ and $77 \cdot 7 \%$, respectively. A search for other homologous proteins in the Swiss-Prot data bank revealed no additional homologies.

The active site of PepX from $L c$. lactis has been identified (Chich et al., 1992) and a sequence resembling that was 
also found from the deduced protein sequence of PepX of Lb. belveticus $53 / 7$ (Fig. 1). The consensus sequences surrounding the active site serine in $L c$. lactis and $L b$. belveticus are G-K-S-Y-L-G and G-R-S-Y-L-G, respectively.

With PC/GENE programs, neither membrane-associated helices nor any putative signal peptide were found in the deduced amino acid sequence of PepX, suggesting intracellular location. In lactococci, both extracellular (Kiefer-Partsch et al., 1989) and intracellular (Meyer et al., 1989; Booth et al., 1990; Zevaco et al., 1990) locations for PepX have been suggested. Tan et al. (1992) found, by using immunoblotting and immunogold labelling, that PepX in Lc. lactis subsp. lactis and Lc. lactis subsp. cremoris was intracellular, although some peripheral labelling was detected. The $\mathrm{N}$-terminal amino acid sequences of the purified PepX proteins from $L c$. lactis subsp. lactis and $L c$. lactis subsp. cremoris were identical to those deduced from the $p e p X$ genes, indicating that the enzymes were not subjected to processing at the $\mathrm{N}$ terminus (Nardi $e t$ al., 1991; Mayo et al., 1991). Furthermore, the sequenced pepX genes of Lc. lactis subsp. lactis, Lc. lactis subsp. cremoris and $L b$. delbrueckii subsp. lactis did not reveal any putative signal sequences. These results strongly support an intracellular location for PepX (Nardi et al., 1991; Mayo et al., 1991; Meyer-Barton et al., 1993).

\section{mRNA analysis}

The size of mRNA transcribed from the $p e p X$ gene was analysed from exponentially growing $L b$. belveticus cells by Northern blotting with a DIG-labelled $p e p X$-specific hybridization probe. The probe detected a $2.6 \mathrm{~kb}$ transcript (Fig. 2), which is in good agreement with the size of the $p e p X$ gene, thus confirming that the $p e p X$ gene is a monocistronic transcriptional unit. The primer extension mapping of the $5^{\prime}$ end of pepX $\mathrm{mRNA}$, performed with total RNA from exponentially growing $L b$. belveticus cells, revealed one transcription start site located 24 nucleotides upstream of the start codon (data not shown). The direct localization of the transcription start site was determined with an automated A.L.F. sequencer by comparing the retention time of the primer extension product with those of the products of a sequencing reaction performed with the same primer. The signal in the sequencing chromatogram with the same retention time as the primer extension signal represents the first nucleotide of the mRNA. The reliability of this method has been tested by localizing the $5^{\prime}$ end of a $L b$. belveticus dipeptidase gene by this and the conventional primer extension methods (unpublished data). The mapping of the $5^{\prime}$ end of the $p e p X$ transcript confirmed the location of the promoter region predicted from the DNA sequence (Fig. 1).

\section{Expression of pepX}

Expression of the pepX $X$ gene in $L b$. belveticus $53 / 7$ was studied in a $\mathrm{pH}$-controlled culture in MRS broth by measuring activity against the gly-pro- $p$ NA substrate and the amount of $p e p X$ transcripts was measured as a function

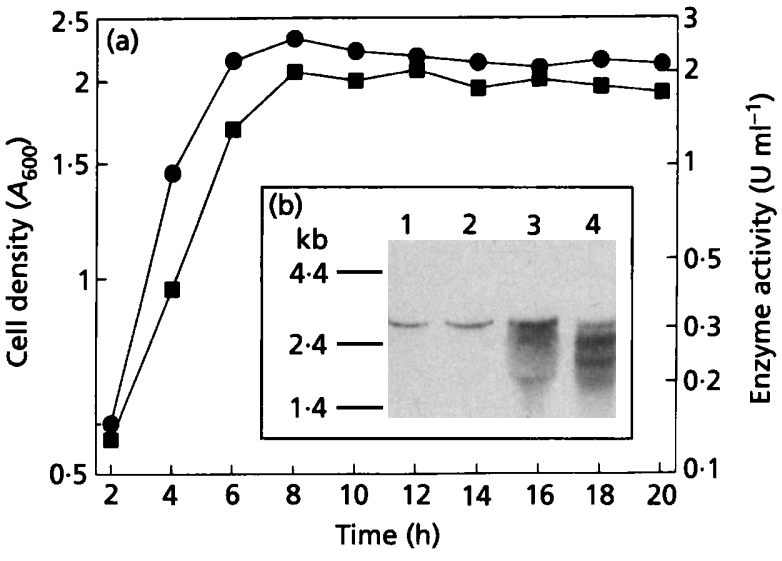

Fig. 2. Expression of the $L b$. helveticus $53 / 7$ pepX as a function of growth. Lb. helveticus 53/7 was grown in 2.5 I MRS broth using a Chemap FZ-3000 bioreactor. The $\mathrm{pH}$ was maintained at 5.85 by the addition of $1 \mathrm{M} \mathrm{NaOH}$. (a) Change in cell density (O) and peptidase activity $(\square)$ against a gly-pro-pNA substrate with time. One unit $(U)$ is defined as the amount of enzyme activity producing a variation of $0.01 A_{410}$ unit $\min ^{-1}$ at $37^{\circ} \mathrm{C}$. (b) Northern blot analysis of the $L b$. helveticus $53 / 7$ pepX transcripts. Total $L b$. helveticus $53 / 7$ RNA, denatured with glyoxal and dimethyl sulfoxide, was run in a $1.0 \%$ agarose gel with $10 \mathrm{mM}$ sodium phosphate buffer, $\mathrm{pH} 6.5$, followed by transfer to a positively charged nylon membrane (Boehringer Mannheim) and hybridization with the DIG-labelled $2.8 \mathrm{~kb}$ pepX-specific PCR fragment. RNA molecular mass markers (BRL) were used to determine the size of transcripts. Lanes 1-4 refer to RNA samples taken $4,6,12$ and $18 \mathrm{~h}$ after inoculation, respectively.

of growth (Fig. 2). The amount of enzyme activity increased up to the early stationary phase of growth reaching the highest level $8 \mathrm{~h}$ after inoculation. During the rest of the growth period analysed, the activity against the gly-pro- $p$ NA substrate remained relatively constant (Fig. 2a). To measure the steady-state level of $p e p X$ transcripts, total RNAs were isolated from $L b$. belveticus cell samples taken 4, 6, 12 and $18 \mathrm{~h}$ after inoculation and analysed by Northern blotting (Fig. 2b). According to the Northern blot data, the steady-state amount of $p e p X$ transcripts was highest during exponential growth, whereas most of the mRNA detected at the stationary phase, was degraded. Like $p e p X$, the level of transcripts of three other $L b$. belveticus peptidase genes ( $p e p C$, $p e p D$ and $p e p R$ ) followed a typical exponential-phase expression (Vesanto $e t$ al., 1994 and unpublished results), whereas the level of the $L b$. belveticus pepN transcripts remained relatively stable in the same conditions throughout the entire growth period analysed (Varmanen et al., 1994).

\section{Overexpression and purification of PepX}

The expression vector was constructed by cloning a $2.5 \mathrm{~kb}$ PCR fragment carrying the $p e p X$ gene into the pKK223-3 vector and designated pKTH2098. The amount of PepX after IPTG-induction increased throughout the entire growth phase of $5 \mathrm{~h}$ as judged by SDS-PAGE, whereas the highest level of PepX activity 


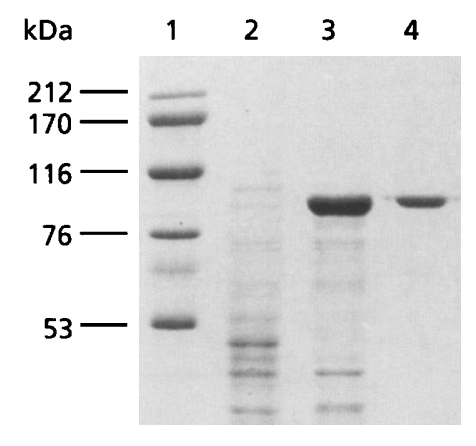

Fig. 3. SDS-PAGE analysis of PepX expression and purification in $E$. coli. Lanes: 1, molecular mass markers; 2 and 3, crude extracts isolated $2 \mathrm{~h}$ after IPTG induction from $E$. coli JM105 with the PKK223-3 vector and from $E$. coli JM105 with pKK223-3 carrying the pepX gene, respectively; 4, purified PepX $(0.7 \mu \mathrm{g})$. Gel electrophoresis was performed in a $10 \%$ polyacrylamide gel followed by staining with Coomassie Brilliant Blue R-250.

was obtained $2 \mathrm{~h}$ after induction (Fig. 3), suggesting the formation of inactive aggregates at the later state of growth. The yield of PepX was up to $10-20 \%$ of the total cellular proteins. Using two chromatographic steps, PepX was purified to homogeneity. The results are summarized in Table 1. The cell-free extract (180 $\mathrm{mg}$ protein) was first fractionated by ammonium sulphate precipitation in two saturation steps (50 and $80 \%$ ). The precipitate formed at $50 \%$ saturation contained only a minority of gly-pro$p \mathrm{NA}$ hydrolysing activity, whereas the second precipitate at $80 \%$ saturation contained the majority of the gly-pro$p \mathrm{NA}$ hydrolysing activity and was used for further purification. In the first chromatographic step, the dialysed and filtered sample was applied onto a QSepharose anion exchange column and eluted in $0-0 \cdot 3 \mathrm{M}$ $\mathrm{NaCl}$ gradient. Gly-pro- $p \mathrm{NA}$ hydrolysing activity eluted at $0.29 \mathrm{M} \mathrm{NaCl}$. During the second step, the active fractions were pooled, concentrated and further purified by hydrophobic interaction chromatography (PhenylSuperose). The major absorbance peak with the maximum PepX activity was detected at $2 \mathrm{M} \mathrm{NaCl}$ and was determined to be an electrophoretically pure enzyme (Fig.

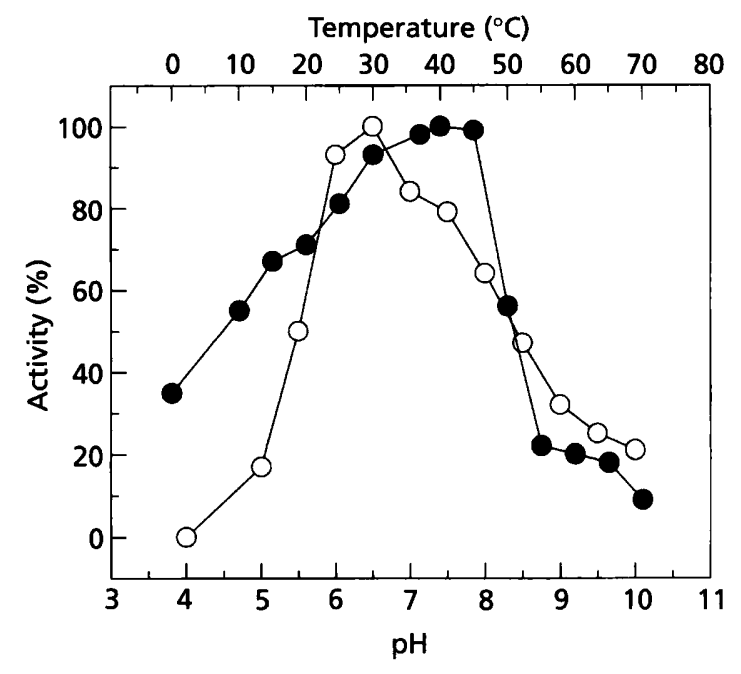

Fig. 4. Effect of temperature (O) and $\mathrm{pH}(O)$ on PepX activity.

3). The specific activity was enriched about 36 -fold and the yield of total activity was $4 \cdot 1 \%$.

\section{Characterization of the purified PepX protein}

The L $b$. belveticus PepX had a sharp $\mathrm{pH}$ optimum at $\mathrm{pH} 6.5$ and a broad temperature optimum between 37 and $45^{\circ} \mathrm{C}$ (Fig. 4). At temperatures above $45^{\circ} \mathrm{C}$, the activity of PepX decreased sharply. These results are in good agreement with the $\mathrm{pH}$ and temperature optima of PepXs from $L b$. acidopbilus and $L b$. delbrueckii subsp. bulgaricus (Bockelmann et al., 1991), Lb. delbrueckii subsp. bulgaricus, $L b$. acidopbilus and $L b$. belveticus CNRZ32 (Khalid \& Marth, 1990). PepX from Lb. belveticus LHE-511 had the same $\mathrm{pH}$ optimum, but the temperature optimum was $50^{\circ} \mathrm{C}$ (Miyakawa et al., 1994). Also higher temperature optima, near $50^{\circ} \mathrm{C}$, have been reported for the PepX enzymes of $L b$. delbrueckii subsp. lactis, $L b$. delbrueckii subsp. bulgaricus and $L b$. case $i$ subsp. case $i$ by Meyer \& Jordi (1987), Miyakawa et al. (1991) and Habibi-Najafi \& Lee (1994). A higher $\mathrm{pH}$ optimum, $\mathrm{pH} 8 \cdot 5$, was reported for the Lc. lactis subsp. lactis PepX (Zevaco et al., 1990).

Table 1. Purification of the cloned $L b$. helveticus 53/7 PepX from $E$. coli JM105

\begin{tabular}{|lccccc|}
\hline $\begin{array}{l}\text { Purification } \\
\text { step }\end{array}$ & $\begin{array}{c}\text { Total protein } \\
\text { (mg) }\end{array}$ & $\begin{array}{c}\text { Total activity } \\
\text { (units)* }\end{array}$ & $\begin{array}{c}\text { Specific } \\
\text { activity } \\
\text { [units (mg } \\
\text { protein) }\end{array}$ & $\begin{array}{c}\text { Purification } \\
\text { factor }\end{array}$ & $\begin{array}{c}\text { Yield activity } \\
\text { (\%) }\end{array}$ \\
\hline Cell-free extract & & & $2 \cdot 5$ & $1 \cdot 0$ & 100 \\
$\left(\mathrm{NH}_{4}\right)_{2} \mathrm{SO}_{4}(80 \%$ saturation) & $380 \cdot 0$ & $442 \cdot 8$ & $2 \cdot 8$ & $1 \cdot 1$ & 24 \\
$\mathrm{Q}^{-S e p h a r o s e}$ & $5 \cdot 0$ & $107 \cdot 3$ & $8 \cdot 7$ & $3 \cdot 5$ & 10 \\
Phenyl-Superose & $0 \cdot 2$ & $43 \cdot 7$ & $90 \cdot 0$ & $36 \cdot 0$ & $4 \cdot 1$ \\
\hline
\end{tabular}

* One unit corresponds to the release of $1 \mu \mathrm{mol} p$-nitroaniline $\mathrm{min}^{-1}$.

† A molar extinction coefficient of $8800 \mathrm{M}^{-1} \mathrm{~cm}^{-1}$ (Bockelmann et al., 1991) was used for $p$-nitroaniline. 
Table 2. Effect of metal ions on PepX activity

Control samples not treated by metal ions are taken as $100 \%$.

\begin{tabular}{|lcc|}
\hline Divalent cation & \multicolumn{2}{c|}{ PepX activity (\%) at ion concentration of: } \\
\cline { 2 - 3 } & $\mathbf{0} \cdot \mathbf{1} \mathbf{~ m M}$ & $\mathbf{1 ~} \mathbf{~ M M}$ \\
\hline Control & 100 & 100 \\
$\mathrm{Mg}^{2+}$ & 69 & 95 \\
$\mathrm{Ca}^{2+}$ & 71 & 108 \\
$\mathrm{Co}^{2+}$ & 86 & 81 \\
$\mathrm{Mn}^{2+}$ & 80 & 102 \\
$\mathrm{Zn}^{2+}$ & 30 & 10 \\
$\mathrm{Cu}^{2+}$ & 10 & 14 \\
$\mathrm{Cd}^{2+}$ & 17 & 12 \\
\hline
\end{tabular}

\section{Table 3. Effect of chemical reagents on PepX activity}

Control samples not treated by chemical reagents are taken as $100 \%$.

\begin{tabular}{|lcc|}
\hline Reagent & \multicolumn{2}{c|}{ PepX activity (\%) at reagent concentration of: } \\
\cline { 2 - 3 } & $\mathbf{0 \cdot 1} \mathbf{~ m M}$ & $\mathbf{1} \mathbf{~ m M}$ \\
\hline Control & 100 & 100 \\
2-Mercaptoethanol & 83 & 101 \\
DTT & 107 & 144 \\
1,10-Phenanthroline & 87 & 69 \\
EDTA & 71 & 108 \\
PMSF & 53 & 24 \\
pHMB & 0 & 0 \\
pHMB + DTT & ND & 162 \\
PHMB + 2-mercaptoethanol & ND & 68 \\
\hline
\end{tabular}

ND, not determined.

Habibi-Najafi \& Lee (1994) reported two optima at $\mathrm{pH} 7 \cdot 0$ and $9 \cdot 5$ for $L b$. case $i$ subsp. case $i$ PepX.

The effect of divalent cations and various inhibitors on the $L b$. belveticus 53/7 PepX are summarized in Tables 2 and 3 , respectively. PepX activity was strongly inhibited by $\mathrm{Cu}^{2+}$ and $\mathrm{Cd}^{2+}$ at concentrations of 0.1 and $1 \mathrm{mM}$ (Table 2 ), which is in good agreement with other PepXs (see references below), except that $\mathrm{Cu}^{2+}$ inhibited only slightly the PepX activity of Lb . casei subsp. casei (Habibi-Najafi \& Lee, 1994). Strain 53/7 PepX was also strongly inhibited by $\mathrm{Zn}^{2+}$. PepX from $L b$. belveticus CNRZ32 was also inhibited by $0.1-2.5 \mathrm{mM} \mathrm{Zn}^{2+}$ (Khalid \& Marth, 1990), in contrast to PepX from Lb. belveticus LHE-511, which was slightly activated by $1 \mathrm{mM} \mathrm{Zn}^{2+}$ (Miyakawa et al., 1994). PepX activity was not inhibited by $1 \mathrm{mM} \mathrm{Ca}^{2+}$ and $\mathrm{Mn}^{2+}$. Other divalent cations such as $1 \mathrm{mM} \mathrm{Mg}^{2+}$ and $\mathrm{Co}^{2+}$ had only a minor effect on the enzyme activity.

The PepX activity was strongly inhibited by 0.1 and $1 \mathrm{mM} p$-hydroxymercuribenzoate $(p \mathrm{HMB})$, partially restored by reducing agents like 2-mercaptoethanol and completely restored by DTT (Table 3 ). This result is similar to PepXs from $L b$. delbrueckii subsp. lactis and $L b$. belveticus (Meyer \& Jordi, 1987; Miyakawa et al., 1991, 1994; Khalid \& Marth, 1990; Miyakawa et al., 1994) and suggests the involvement of a sulfhydryl group in catalysis. Alternatively, the inhibition might be due to the steric hindrance by the thiol modifying agent rather than the direct role of cysteine in catalysis. DTT and 2mercaptoethanol alone had no effect on enzyme activity, indicating that intact disulfide groups were not essential for enzyme activity. PepXs from $L b$. case $i$ subsp. case $i$ and Lc. lactis subsp. lactis were, however, not inhibited by sulfhydryl inhibitors such as iodoacetate or $p \mathrm{HMB}$, indicating that no functional sulfhydryl group was involved in catalysis in these enzymes (Habibi-Najafi \& Lee, 1994 ; Zevaco et al., 1990; Lloyd \& Pritchard, 1991). EDTA at concentration of $1 \mathrm{mM}$ had no effect on PepX activity, while 1,10-phenanthroline, another potential metallo-protease inhibitor reduced the activity slightly (Table 3). This result is similar to PepXs from $L b$. belveticus, $L b$. delbrueckii subsp. bulgaricus and $L$ b. acidophilus (Khalid \& Marth, 1990; Miyakawa et al., 1994; Bockel- 
mann et al., 1991). The addition of the serine enzyme inhibitor, PMSF, reduced activity to about $24-53 \%$, indicating that the active site includes a serine residue. This result is consistent with results obtained with PepXs from Lb. belveticus CNRZ32, Lb. belveticus LHE-511 and Lb. casei subsp. casei (Khalid \& Marth, 1990; Miyakawa et al., 1994; Habibi-Najafi \& Lee, 1994).

The affinity of $L b$. belveticus $53 / 7$ PepX for the gly-pro$p$ NA substrate $(10-1000 \mu \mathrm{M}$ final concentration) was studied by measuring the initial rate of the reaction with a continuous assay in thermostat-controlled cuvettes at $40^{\circ} \mathrm{C}, \mathrm{pH} 6.5$. The $K_{\mathrm{m}}$ value of $280 \mu \mathrm{M}$ was calculated by non-linear regression analysis. For the PepX from several lactic acid bacteria, $K_{\mathrm{m}}$ values of $284,289,451$ and $71 \mu \mathrm{M}$ have been reported (Bockelmann et al., 1991).

The molecular mass for the native enzyme was calculated to be around $165 \mathrm{kDa}$ by gel filtration, indicating that the enzyme probably consists of two subunits. The discrepancy between the observed dimer molecular mass and the molecular mass expected from the monomeric size might be due to the shape of the PepX dimer when compared to the globular marker proteins. A dimer form has also been reported for PepXs from S. thermophilus, Lc. lactis subsp. cremoris, Lc. lactis subsp. lactis, Lb. delbrueckii subsp. bulgaricus and $L b$. delbrueckii subsp. lactis with molecular sizes of 150-200 kDa (Meyer \& Jordi, 1987; Kiefer-Partsch et al., 1989; Zevaco et al., 1990, Lloyd \& Pritchard, 1991; Bockelmann et al., 1991). Booth et al. (1990) calculated a molecular mass of $117 \mathrm{kDa}$ for the active form of the PepX from Lc. lactis subsp. cremoris. In contrast to our results, monomer forms have been described for $L b$. helveticus CNRZ32 and LHE-511, where the molecular mass of CNRZ32 PepX was estimated only by native PAGE (Khalid \& Marth, 1990; Miyakawa et al., 1994). Moreover, a monomer form has been described for Lb. delbrueckii subsp. lactis, $L b$. delbrueckii subsp. bulgaricus and Lb. casei subsp. casei (Atlan et al., 1990; Meyer-Barton et al., 1993; Habibi-Najafi \& Lee, 1994) and also a trimer form with a molecular mass of $270 \mathrm{kDa}$ for $L b$. delbrueckii subsp. bulgaricus (Miyakawa et al., 1991). Some of the differences in molecular masses for the native PepXs might be due to the slight variations in $\mathrm{pH}$ and $\mathrm{NaCl}$ concentrations in gel filtration.

In conclusion, we have characterized the X-prolyl dipeptidyl aminopeptidase (PepX) gene and protein of an industrial $L b$. helveticus strain. The $p e p X$ gene was shown to be a monocistronic transcriptional unit having a typical exponential-phase expression. The PepX protein was overexpressed in E. coli and purified to homogeneity by only two steps. The purified PepX protein was shown to be a dimeric intracellular serine peptidase possessing characteristics closely resembling those of other X-prolyl dipeptidyl aminopeptidases.

\section{ACKNOWLEDGEMENTS}

This work was supported by the Ministry of Agriculture and Forestry of Finland. The authors are grateful to Mrs Anneli Virta for the running of the A.L.F. Sequencer and Ms Jaana Jalava for technical assistance.

\section{REFERENCES}

Atlan, D., Laloi, P. \& Portalier, R. (1990). X-prolyl-dipeptidyl aminopeptidase of Lactobacillus delbrueckii subsp. bulgaricus: characterization of the enzyme and isolation of deficient mutants. Appl Environ Microbiol 56, 2174-2179.

Baankreis, R. \& Exterkate, F. (1991). Characterization of a peptidase from Lactococcus lactis subsp. cremoris HP that hydrolyses di- and tripeptides containing proline or hydrophobic residues as the aminoterminal amino acid. System Appl Microbiol 14, 317-323.

Bockelmann, W., Fobker, M. \& Teuber, M. (1991). Purification and characterization of the X-prolyl-dipeptidyl-aminopeptidase from Lactobacillus delbrueckii subsp. bulgaricus and Lactobacillus acidophilus. Int Dairy Journal 1, 51-66.

Booth, M., Fhaolain, I. N., Jennings, P. V. \& O'Cuinn, G. (1990). Purification and characterization of a post-proline dipeptidyl aminopeptidase from Streptococcus cremoris AM2. J Dairy Res 57, 89-99.

Casey, M. G. \& Meyer, J. (1985). Presence of X-prolyl-dipeptidylpeptidase in lactic acid bacteria. J Dairy Sci 68, 3212-3215.

Chich, J.-F., Chapot-Chartier, M.-P., Ribadeau-Dumas, B. \& Gripon, J.-C. (1992). Identification of the active site serine of the Xprolyl dipeptidyl aminopeptidase from Lactococcus lactis. FEBS Lett 314, 139-144.

El Soda, M. \& Desmazeaud, M. (1982). Les peptide hydrolases des lactobacilles du groupe Thermobacterium. I. Mise en évidence de ces activités chez Lactobacillus belveticus, $L$ acidophilus, $L$. lactis et $L$. bulgaricus. Can J Microbiol 28, 1181-1188.

Fox, P. (1989). Proteolysis during cheese manufacture and ripening. J Dairy Sci 72, 1379-1400.

Habibi-Najafi, M. B. \& Lee, B. H. (1994). Purification and characterization of X-prolyl dipeptidyl peptidase from Lactobacillus casei subsp. casei LLG. Appl Microbiol Biotechnol 42, 280-286.

Hames, B. \& Higgins, S. (1985). Nucleic Acid Hybridisation: a Practical Approach. Oxford: IRL Press.

Khalid, N. M. \& Marth, E. H. (1990). Purification and partial characterization of a prolyl-dipeptidyl aminopeptidase from Lactobacillus belveticus CNRZ 32. Appl Environ Microbiol 56, 381-388.

Kiefer-Partsch, B., Bockelmann, W., Geis, A. \& Teuber, M. (1989). Purification of an X-prolyl-dipeptidyl aminopeptidase from the cell wall proteolytic system of Lactococcus lactis subsp. cremoris. Appl Microbiol Biotechnol 31, 75-78.

Kok, J. (1990). Genetics of the proteolytic system of lactic acid bacteria. FEMS Microbiol Rev 87, 15-42.

Kok, J. \& De Vos, W. (1994). The proteolytic system of lactic acid bacteria. In Genetics and Biotechnology of Lactic Acid Bacteria, pp. 169-210. Edited by M. J. Gasson \& W. M. De Vos. Glasgow: Blackie.

Laemmli, U. K. (1970). Cleavage of structural proteins during the assembly of the head of bacteriophage T4. Nature 227, 680-685.

Lloyd, R. J. \& Pritchard, G. G. (1991). Characterization of X-prolyl dipeptidyl aminopeptidase from Lactococcus lactis subsp. lactis. J Gen Microbiol 137, 49-55.

Mayo, B., Kok, J., Venema, K., Bockelmann, W., Teuber, M., Reinke, H. \& Venema, G. (1991). Molecular cloning and sequence analysis of the $\mathrm{X}$-prolyl dipeptidyl aminopeptidase gene from Lactococcus lactis subsp. cremoris. Appl Environ Microbiol 57, 38-44.

Meyer, J. \& Jordi, R. (1987). Purification and characterization of Xprolyl-dipeptidyl-aminopeptidase from Lactobacillus lactis and from Streptococcus thermophilus. J Dairy Sci 70, 738-745.

Meyer, J., Howald, D., Jordi, R. \& Fürst, M. (1989). Location of proteolytic enzymes in Lactobacillus lactis and Streptococcus thermo- 
philus and their influence on cheese ripening. Milchwissenschaft 44, 678-681.

Meyer-Barton, E. C., Klein, J. R., Imam, M. \& Plapp, R. (1993). Cloning and sequence analysis of the X-prolyl-dipeptidylaminopeptidase gene ( $p e p X$ ) from Lactobacillus delbrueckii subsp. lactis DSM7290. Appl Microbiol Biotechnol 40, 82-89.

Miyakawa, H., Kobayashi, S., Shimamura, S. \& Tomita, M. (1991). Purification and characterization of an X-prolyl dipeptidyl aminopeptidase from Lactobacillus delbrueckii subsp. bulgaricus LBU-147. J Dairy Sci 74, 2375-2381.

Miyakawa, H., Hashimoto, I., Nakamura, T., Ishibashi, N., Shimamura, S. \& Igoshi, K. (1994). Purification and characterization of an X-prolyl dipeptidyl aminopeptidase from Lactobacillus belveticus LHE-511. Milchwissenschaft 49, 670-673.

Myöhănen, S. \& Wahlfors, J. (1993). Automated fluorescent primer extension. BioTechniques 14, 16-17.

Nardi, M., Chopin, M.-C., Chopin, A., Cals, M.-M. \& Gripon, J.-C. (1991). Cloning and DNA sequence analysis of an X-prolyl dipeptidyl aminopeptidase gene from Lactococcus lactis subsp. lactis NCDO 763. Appl Environ Microbiol 57, 45-50.

Nowakowski, C. M., Bhowmik, T. K. \& Steele, J. L. (1993). Cloning of peptidase genes from Lactobacillus belveticus CNRZ32. Appl Microbiol Biotechnol 39, 204-210.

Pritchard, G. \& Coolbear, T. (1993). The physiology and biochemistry of the proteolytic system in lactic acid bacteria. FEMS Microbiol Rev 12, 179-206.

Sambrook, J., Fritsch, E. F. \& Maniatis, T. (1989). Molecular Cloning: a Laboratory Manual, 2nd edn. Cold Spring Harbor, NY: Cold Spring Harbor Laboratory.

Sanger, F., Nicklen, S. \& Coulson, A. R. (1977). DNA sequencing with chain-terminating inhibitors. Proc Natl Acad Sci USA 74, 5463-5467.

Shine, J. \& Dalgarno, L. (1974). Determinant of cistron specificity in bacterial ribosomes. Nature 254, 34-38.
Stormo, G. D., Schneider, T. D. \& Gold, L. M. (1982). Characterization of translational initiation sites in E. coli. Nucleic Acids Res 10, 2971-2996.

Tan, P. S. T., Chapot-Chartier, M.-P., Pos, K. M., Rousseau, M., Boquien, C.-Y., Gripon, J.-C. \& Konings, W. N. (1992). Localization of peptidases in lactococci. Appl Environ Microbiol 58, 285-290.

Tan, P., Poolman, B. \& Konings, W. (1993). Proteolytic enzymes of Lactococcus lactis. J Dairy Res 60, 269-286.

Varmanen, P., Vesanto, E., Steele, J. L. \& Palva, A. (1994). Characterization and expression of the $p e p N$ gene encoding a general aminopeptidase from Lactobacillus belveticus. FEMS Microbiol Lett 124, 315-320.

Vesanto, E., Varmanen, P., Steele, J. L. \& Palva, A. (1994). Characterization and expression of the Lactobacillus helveticus pepC gene encoding a general aminopeptidase. Eur $J$ Biochem 224, 991-997.

Visser, S. (1993). Proteolytic enzymes and their relation to cheese ripening and flavor: an overview. J Dairy Sci 76, 329-350.

Woodcock, D., Crowther, P., Doherty, J., Jefferson, S., De Cruz, E., Noyer-Weidner, M., Smith, S., Michael, M. \& Graham, M. (1989). Quantitative evaluation of Escherichia coli host strains for tolerance to cytosine methylation in plasmid and phage recombinants. Nucleic Acids Res 17, 3469-3478.

Yoshpe-Besancon, I., Gripon, J.-C. \& Ribadeau-Dumas, B. (1994). Xaa-Pro-dipeptidyl-aminopeptidase from Lactococcus lactis catalyses kinetically controlled synthesis of peptide bonds involving proline. Biotechnol Appl Biochem 20, 131-140.

Zevaco, C., Monnet, V. \& Gripon, J.-C. (1990). Intracellular Xprolyl dipeptidyl peptidase from Lactococcus lactis subsp. lactis: purification and properties. J Appl Bacteriol 68, 357-366.

Received 16 May 1995; revised 6 August 1995; accepted 11 August 1995. 